\section{From Palæolithic to Neolithic in Britain}

The Mesolithic Age in Britain. By J. G. D. Clark. Pp. xxiii +223. (Cambridge : At the University Press, 1932.) 15s. net.

$\mathrm{N}$ most departments of life, each generation is prone to regard its immediate predecessor as living in outer darkness; but it is scarcely fair of Mr. Clark to single out an ipse dixit which gained few, if any, adherents as an index of ignorance concerning the later stone age twenty years ago. It is, however, unquestionable that it is only during the last ten to fifteen years that archæological discovery has provided the material which has made possible, and indeed demanded, scientific treatment of the period between the upper palæolithic and neolithic, regarded by older archæologists not so long ago as a gap, on the scale and in such detail as it receives in Mr. Clark's "The Mesolithic Age in Britain".

Almost entirely within the present centuryit was in 1895 only that Piette explored Mas d'Azil-archæological research has established a number of cultures, estimated by one archæologist at seven, which now fill the former palæolithicneolithic gap, for which, as a whole, various names are in use. Mr. Clark on logical and typological grounds elects 'mesolithic'. It covers from the end of the Pleistocene to the full intrusive neolithic of the food-producers and the long barrow. Thus, it will be seen, he eliminates 'early neolithic' and makes the whole period cover some four millennia on de Geer's chronology. This seems excessive, and Mr. Clark himself seems to regard it with some doubt; but it accords with the facts as at present known, and agrees with the present trend of thought, which moves in the direction of reducing the neolithic to narrow dimensions in time. It does, however, make easier of acceptance the survival of mesolithic types of stone implements into the bronze age. But Mr. Clark stresses emphatically that the period is not "transitional", since the cultures are "off the line of human progress".

As regards the cultures, Britain as a peripheral area is both derivative and original. Continental types are locally developed. Thus the Azilian, now accepted as established and at an early date in north-west Britain, exhibits local differences in the characteristic harpoons and associated implements, while at Creswell, it is suggested as a hypothesis, the Upper Palæolithic itself showed a microlithic tendency before the Tardenoisian appears. Even after its arrival Tardenoisian continues to exhibit Continental influence. Thus while Early Tardenoisian is found so far apart as the Isle of Wight and the Pennines and Northumbria, and, Mr. Clark thinks, may underlie the industries of the south of England, Middle Tardenoisian influences come in from Belgium and are to be seen at their best in the Isle of Man; while Late Tardenoisian appears in the neat geometric forms of Wangford, Scunthorpe and the Pennines. This last is absent in what Mr. Clark calls Province B, south-east Britain, where axes or picks with tranchet cutting-edges and mesolithic points of non-geometrical type--industries in fact comparable with Maglemosian and Campignianappear early in the mesolithic period, and occupy substantially the same period as the evolution of the mesolithic industries of Province A which covers the rest of the country.

Mr. Clark's survey of the evidence now available is an excellent piece of work. When much has still, we hope, to be discovered, it can possess no finality; but it will have to be taken into account in all future work on the period.

\section{Foraminifera of the South Atlantic}

Discovery Reports. Issued by the Discovery Committee, Colonial Office, London, on behalf of the Government of the Dependencies of the Falkland Islands. Vol. 4. Foraminifera. Part 1: The Ice-free Area of the Falkland Islands and adjacent Seas. By Edward Heron-Allen and Arthur Earland. Pp. 291-460+plates 6-17. (Cambridge: At the University Press, 1932.) 25s. net.

THE Falkland Islands area has a particular historical interest for the students of the Foraminifera, for it was in this region that d'Orbigny, the pioneer of the systematics of this group, obtained an important part of the material on which his great work was based. It is a matter for congratulation that this collection, much larger and from a wider area round the Islands than d'Orbigny's, has, a hundred years later, fallen into the capable and experienced hands of the authors of this very fine report.

It is interesting to find that as a general result of the determination of the species, they are able to confirm d'Orbigny's opinion that the foraminiferal fauna of the South Atlantic is quite distinct 